\title{
A Study on Characteristics of Subgrade Soil by Use of Foundry Sand and Iron Turnings
}

\author{
Brajesh Mishra \\ M. Tech., Assistant Engineer, U.P. Cane Development Department, Lucknow, India
}

\begin{abstract}
It is due to continuous increase in industrial by-products and wastes, solid waste management in present scenario has become a global environmental concern. Due to costly disposal of waste materials and shortage of landfills, it is the need of the hour to reuse the waste materials in various construction activities in a eco-friendly way. Foundry sand is one of such industrial by-product causing hazardous effect on environment and human being. The natural properties of foundry sand can be used to utilize it in sub-grade of a pavement to avoid any possible threat to environment and giving a way for safe and economical disposal of the same. Other industrial waste is iron turnings which can also be reused. This study is about the improvement of compaction and sub-grade characteristics of sandy clayey soil by blending it with foundry sand and iron turnings in specified proportions. The various strength parameters i.e. compaction characteristics and California Bearing Ratio (CBR) of different mix proportions of soil, foundry sand along with iron turnings were studied. It was observed that the Maximum Dry Density(MDD) and California Bearing Ratio (CBR) values increases up to certain proportion of addition of foundry sand in sandy clayey soil and thereafter on further addition of foundry sand it starts decreasing. The same trend was also observed with the introduction of iron turnings in selected soil-foundry sand mixture. As a result a suitable composition with optimum percentage of clayey soil, foundry sand and iron turnings was found, which can be effectively used in the construction of sub-grade of roads and embankments giving a way for good and economical construction.
\end{abstract}

Keywords: California Bearing Ratio (CBR), Maximum Dry Density(MDD), Foundry sand, Iron turnings, Industrial by-product.

\section{Introduction}

A large amount of sand as a part of metal casting process is used in Metal foundries. In the process sand is recycled and reused many times. When the sand can not be further utilized in the foundry process, it is removed and termed as "foundry sand". It is high quality silica sand which is a by-product of casting process of ferrous and nonferrous metals. The properties of foundry sand is dependent on type of casting process and the type of industry. High quality silica sands are used by the industries in their metal casting process. Foundry sand consists of green sand and resin sand. Green sand typically comprise of high quality silica-sand, 5to $10 \%$ bentonite clay, 2 to $5 \%$ water and around 5\% sea coal. Green sand is most commonly used around $90 \%$ of the molding material by foundries. Resin sands are high- quality silica sand usually held together with organic binder in conjunction with catalyst in different hardening procedures. Resin sands are mostly used for "cores" that produce cavities that are not practical to produce by green sand molding operations.

Table 1: Typical properties of green foundry sand

\begin{tabular}{|c|c|c|}
\hline Property & Value & Test Method \\
\hline Specific gravity & $2.40-2.70$ & ASTM 854-06 \\
\hline Bulk Density gm/cc & 1.60 & AASHTO T084 \\
\hline Absorption \% & $0.76-6.20$ & ASTM C128 \\
\hline Moisture Content \% & $0.10-15.0$ & ASTM D 2216 \\
\hline Hydraulic conductivity & $10^{-3}$ to $10^{-} 9$ & ASTM D 5084 \\
\hline $\begin{array}{c}\text { California Bearing Ratio } \\
\text { (CBR)\% }\end{array}$ & Average 20 & ASTM D 1883 \\
\hline $\begin{array}{c}\text { Internal friction angle } \\
\text { Magnesium sulphate } \\
\text { soundness loss \% }\end{array}$ & $33^{\circ}-43^{\circ}$ & ASTM D 3080 \\
\hline \multicolumn{2}{|c|}{5} & ASTM C88-05 \\
\hline
\end{tabular}

Foundry sand is basically fine aggregate. It can be used in following ways-
- Same way as natural sand

- In embankments \& other similar civil engineering applications

- Flow able fills

- Hot mix asphalts and Plain cement concrete (PCC)

- Agriculturally as top soil

In engineering applications in India at present foundry sand around 5 to 7 lacs tones is used annually. Due to paucity of funds in India specially for low volume village roads there is a requirement of cheaper materials for construction. Foundry sand along with iron turnings and locally available materials can be used in embankments and sub-base of rural roads. So one can utilize a large volume of foundry sand in road construction projects to minimize the cost of construction. Many researchers in past have shown that foundry sand can be used successfully in various civil engineering construction. Some of those are listed below-

- Highway bases and retaining structures (Kirk,1998: Mast and Fox,1998: Goodhue et al,2001)

- Landfill Liners (Abichou et al, 1998, 2004)

- Asphalt concrete (Javeb and Lovell,1995)

- Flow able fill (Bhat and Lovell,1996)

- Pavement bases (Kleven et al,2000)

Existing research has shown that foundry sand can play its role in geotechnical construction due to its comparable properties with sand-bentonite mixtures. (Abichou et al, 2004)

\subsection{Need for Utilization of Foundry sand}

In India at present around 6500 foundries are in operation with a total casting output around 2.8 million tones. India is a leading producer of casting in the world. The foundry units in India are mostly located in Rajkot, Agra, Howrah, Jamnagar, Kolhapur, Coimbatur and Hyderabad. Annually around 2 million tones of foundry sand waste is produced in

\section{Volume 4 Issue 12, December 2015}




\section{International Journal of Science and Research (IJSR) \\ ISSN (Online): 2319-7064}

Index Copernicus Value (2013): 6.14 | Impact Factor (2014): 5.611

India and 9 million tones in United States as a by-product of metal casting industries. Laboratory investigations indicate that WFS from ferrous foundries can provide the necessary engineering properties for a highway embankment and bioassay test can be used to screen the ,toxicity of WFS to prevent a negative environmental impact (Edil et al, 2002).

\section{Objectives}

In present study an attempt is made to study the possibility of using foundry sand and iron turnings in combination with the soil to get an improved soil material which may be used in sub-grade of a pavement and other structures. Foundry sand sample was obtained from a foundry of Agra city of Uttar Pradesh, a state of India. The objectives of current work were as under-

1)Clayey soil and foundry sand were mixed in different proportions and optimized for maximum dry density.

2)Foundry sand content was varied from $0 \%$ to $40 \%$ with a increment of $10 \%$.(i.e. $0 \%, 10 \%, 20 \%, 30 \%$ and $40 \%$ ) to optimize its value on maximum dry density and CBR value of suitable clay-foundry sand mixture.

3) To find out technically most viable combination of clayey soil and foundry sand with varying percentage of iron turnings at the optimum moisture content and maximum dry density.

4) To find most appropriate and viable combination on the basis of maximum dry density and CBR values.

\section{Materials and Method}

The locally available soil in this study was used. Foundry sand (FS) sample was obtained from a foundry of Agra city of Uttar Pradesh, a state of India. According to soil classification of soil it was classified as sandy clay(SC).

Table 2: Basic properties of soil and foundry sand

\begin{tabular}{|l|c|c|}
\hline \multicolumn{1}{|c|}{ Particulars } & Soil & F.S. \\
\hline Specific Gravity (IS:2720-III-1980) & 2.68 & 2.56 \\
\hline Coefficient of uniformity Cu & - & 1.88 \\
\hline Coefficient of curvature Cc & - & 0.98 \\
\hline IS soil classification & SC & SP \\
\hline Liquid Limit \% (IS:2720-V-1975) & 28 & NP \\
\hline Plastic Limit \% & 18.6 & NP \\
\hline Maximum dry density(g/cc) (IS:2720-VII-1980) & 1.78 & 1.76 \\
\hline Optimum moisture content \% (IS:2720-VII-1980) & 12.8 & 9.6 \\
\hline California Bearing Ratio (CBR)\% & 6.12 & 16.8 \\
\hline
\end{tabular}

The particle size distribution (PSD) curve for soil and foundry sand are shown in Fig-4(IS:2720-IV-1975). The iron turnings were obtained from mild steel turnings produced from metal working operations on lathe machine in local workshop which are generally wasted as scrap. The properties of iron turnings are those of mild steel given below-

- Composition- $2 \%$ carbon, $1.65 \%$ manganese, $0.6 \%$ copper and $0.6 \%$ silicon

- Specific gravity $=7.85$, Younges Modulus $=210000$ $\mathrm{N} / \mathrm{mm}^{2}$

The iron turnings were crushed to size ranging from 3 to 5 $\mathrm{mm}$ be used as reinforcement in soil- foundry sand mix.

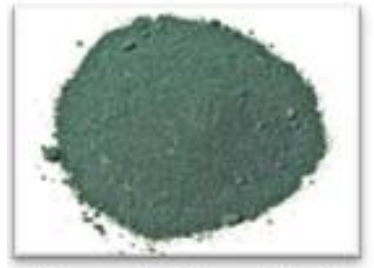

Figure 1: Green Sand

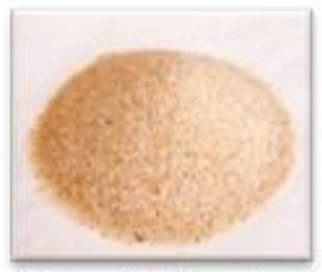

Figure 2:Silica Sand

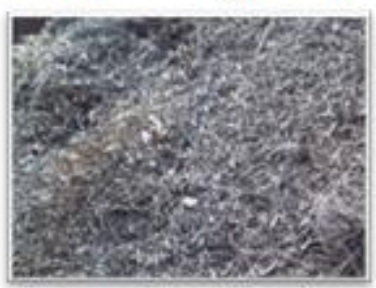

Figure 3: Iron Tumings

The type of foundry sands i.e. green sand and silica sand are shown in Fig-1 \&2. The iron turnings are shown in Fig-3.

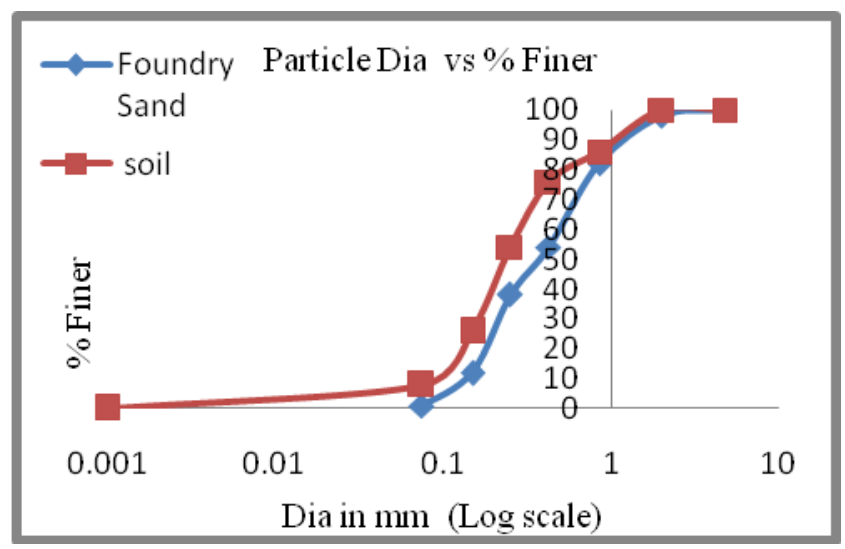

Figure 4: Particle Size Distribution of Soil and Foundry Sand

\subsection{Method}

The laboratory investigations were carried out in two steps:

1. Blending of soil sample with foundry sand in different percentages i.e. $0 \%, 10 \%, 20 \%, 30 \%$ and $40 \%$ by weight of soil.

2. Blending of soil sample with $20 \%$ foundry sand for different percentages of iron turnings i.e. $1 \%, 2 \%, 3 \%$ and $4 \%$ by weight of soil and foundry sand mix.

The study of tests was carried out in two steps. In first step moisture density relation (IS light compaction test) and CBR were evaluated for the soil blended with varying percentages of foundry sand. In the second step effect of iron turnings for soil blended with $20 \%$ of foundry sand content on moisture density relation (IS light compaction test) and CBR (unsoaked) were evaluated

\section{Results and Discussions}

\subsection{Compaction Characteristics}

IS Light compaction test was carried out on various proportions of foundry sand and soil in accordance with the procedure laid in IS:2720-VII-1980 to study moisture and density relationship. 


\section{International Journal of Science and Research (IJSR) \\ ISSN (Online): 2319-7064}

Index Copernicus Value (2013): 6.14 | Impact Factor (2014): 5.611

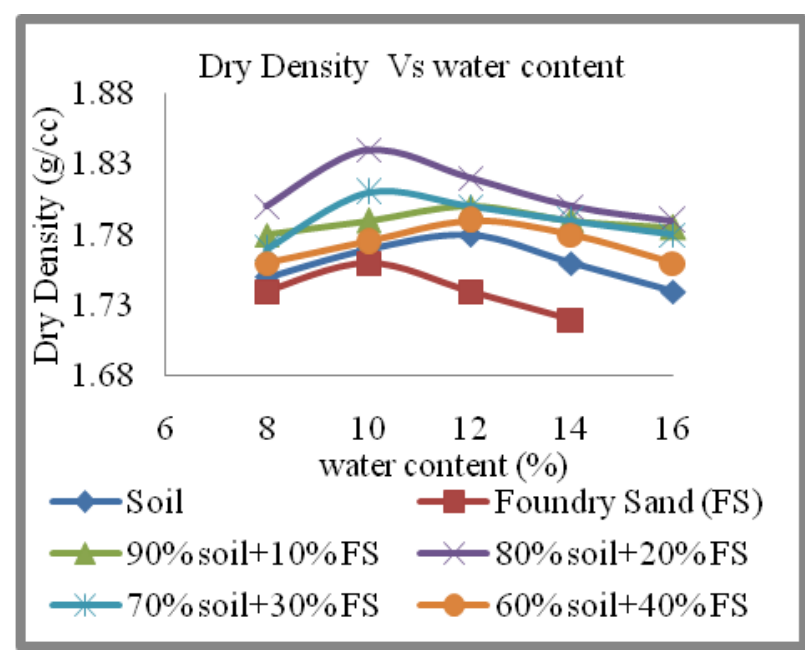

Figure 5: Variation of Dry Density of Soil with Foundry Sand Content

It is clearly seen from the curves in Fig-5 that initially dry density increases on addition of foundry sand up to a specified value and then on further addition of foundry sand it goes on decreasing. The maximum dry density was observed on $80 \%$ soil $+20 \%$ foundry sand combination.

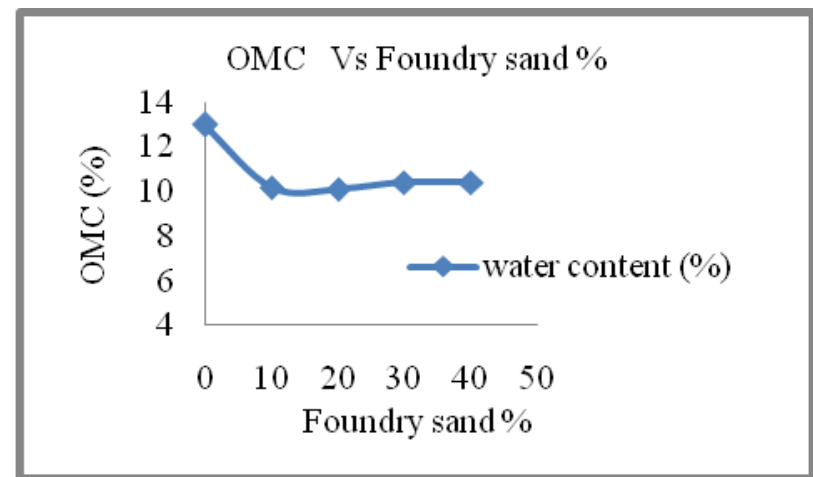

Figure 6: Variation of Optimum Moisture Content (OMC) with Foundry Sand

It was observed seen from the Fig-6 that initially Optimum Moisture Content (OMC) decreases with addition of foundry Sand up to a specified value and then on further addition of foundry sand it goes on increasing. The minimum Optimum Moisture Content (OMC) was observed at $80 \%$ soil $+20 \%$ foundry sand combination.

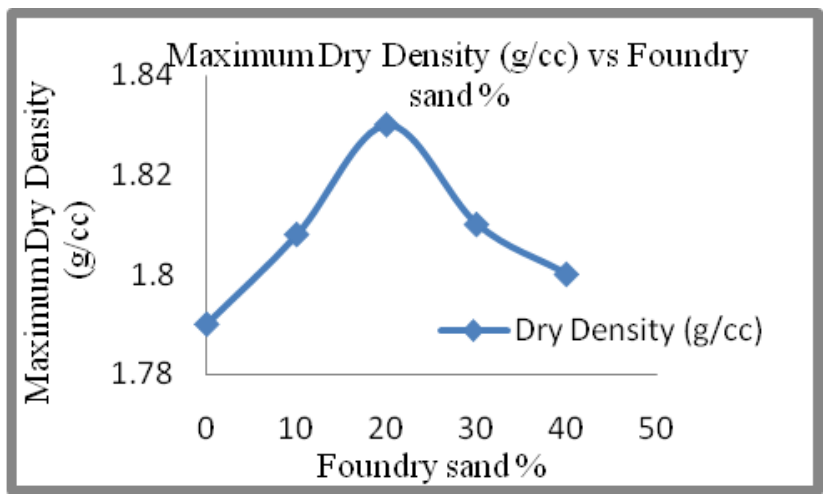

Figure 7: Variation of the Maximum Dry Density (MDD) with Foundry Sand
It was observed from the Fig-7 that initially Maximum Dry Density (MDD) increases with addition of foundry Sand up to a specified value and then on further addition of foundry sand it goes on decreasing. The Maximum Dry Density (MDD) was observed at $80 \%$ soil $+20 \%$ foundry sand combination.

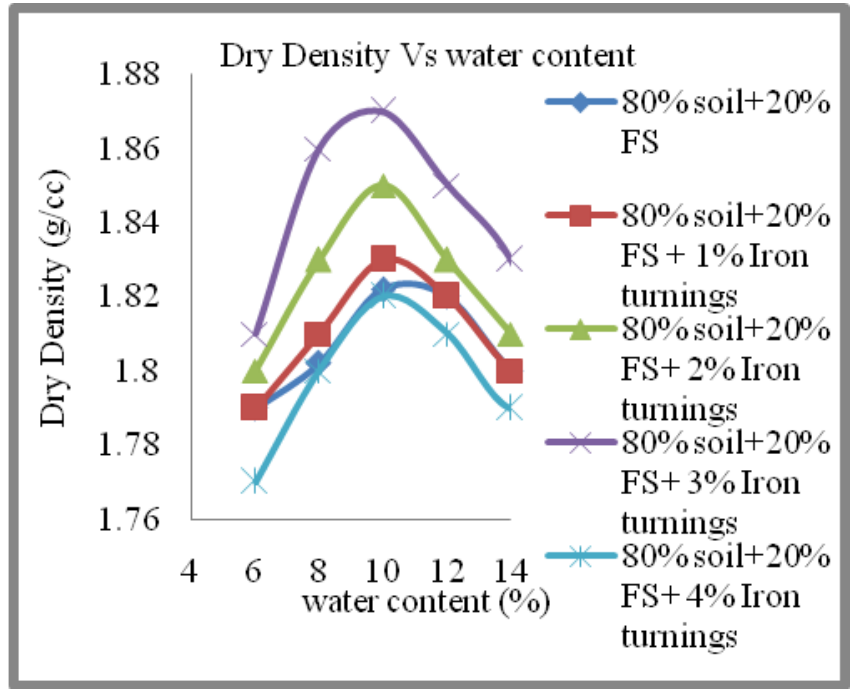

Figure 8: Variation of Dry Density of $80 \%$ Soil $+20 \%$ Foundry Sand with Iron Turnings

It was observed from the Fig-8 that initially Dry Density increases with addition of iron turnings in a combination mix of $80 \%$ Soil $+20 \%$ foundry Sand up to a specified value and then on further addition of iron turnings it goes on decreasing. The Maximum Dry Density (MDD) was observed at $80 \%$ soil $+20 \%$ foundry sand combination with addition of $3 \%$ iron turnings by weight of $80 \%$ soil $+20 \%$ foundry sand mix.

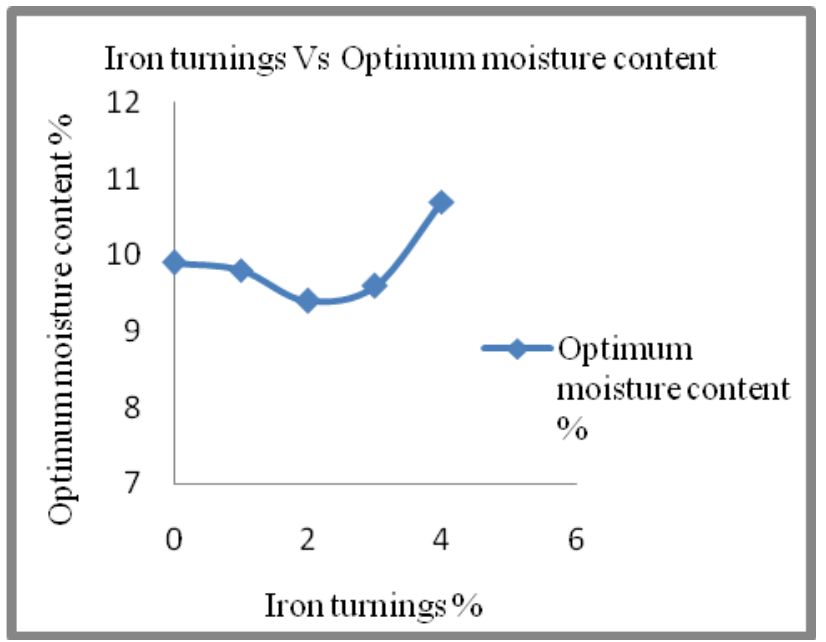

Figure 9: Variation of OMC with Iron Turnings Content for $80 \%$ Soil $+20 \%$ FS

It was observed from the Fig-9 that initially OMC decreases with addition of iron turnings in a combination mix of $80 \%$ Soil $+20 \%$ foundry Sand up to a specified value and then on further addition of iron turnings it goes on increasing. The minimum value of OMC was observed at $80 \%$ soil $+20 \%$ foundry sand combination with addition of 3\% iron turnings by weight of $80 \%$ soil $+20 \%$ foundry sand mix. 


\section{International Journal of Science and Research (IJSR) \\ ISSN (Online): 2319-7064}

Index Copernicus Value (2013): 6.14 | Impact Factor (2014): 5.611

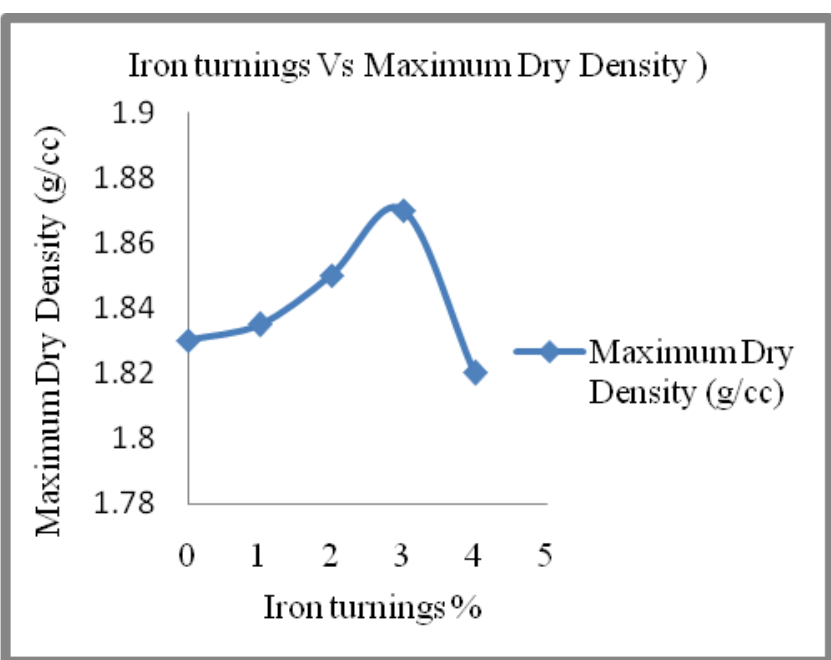

Figure 10: Variation of MDD with Iron Turnings Content for $80 \%$ Soil $+20 \%$ FS

It was observed from the Fig-10 that initially MDD increases with addition of iron turnings in a combination mix of $80 \%$ Soil $+20 \%$ foundry Sand up to a specified value and then on further addition of iron turnings it goes on decreasing. The iron turnings have more surface area so when percentage of iron turning is increased beyond the optimum value more void spaces were created resulting in a decrease in value of MDD. The maximum value of MDD was observed at $80 \%$ soil $+20 \%$ foundry sand combination with addition of $3 \%$ iron turnings by weight of $80 \%$ soil $+20 \%$ foundry sand mix.

\subsection{Strength Characteristics}

The California Bearing Ratio (CBR) test was performed on un-soaked and soaked condition samples on soil mixed with varying percentages of foundry sand by weight of soil to study the load bearing capacity.

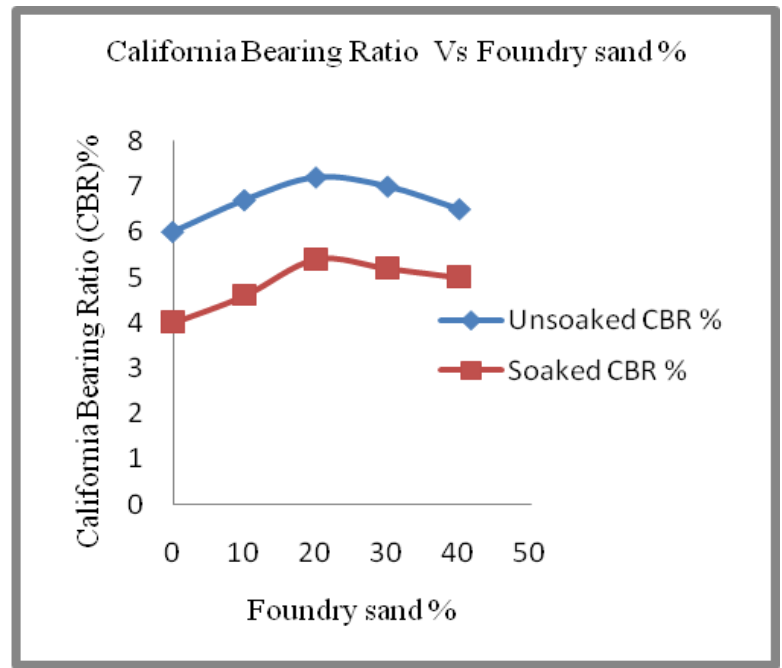

Figure 11: Variation of California Bearing Ratio (CBR) Value for $80 \%$ Soil $+20 \%$ FS

It is clearly seen from the curves in Fig-11 that initially California Bearing Ratio (CBR) Value increases on addition of foundry sand up to a specified value and then on further addition of foundry sand it goes on decreasing. The maximum California Bearing Ratio (CBR) Value was observed on $80 \%$ soil $+20 \%$ foundry sand combination for both un-soaked and soaked condition samples.

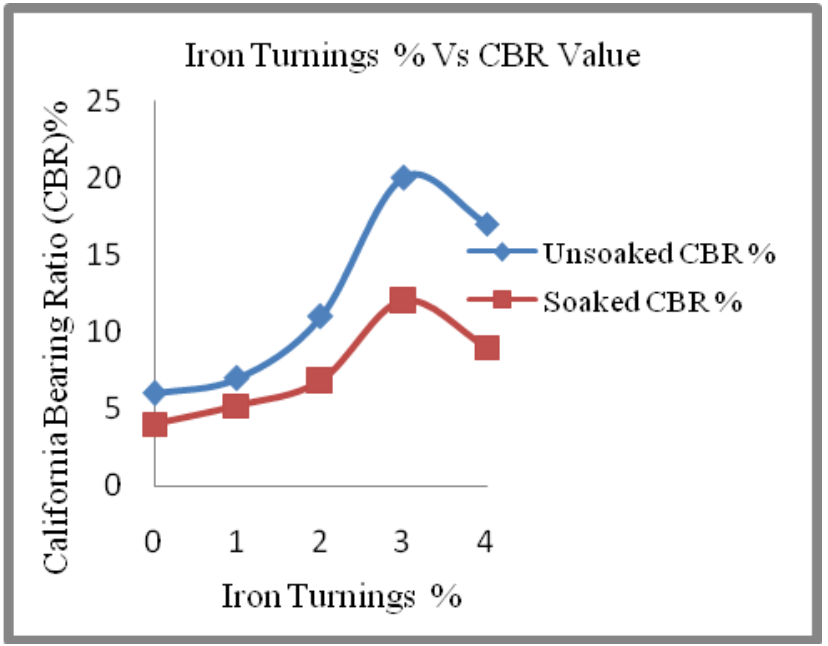

Figure 12: Variation of CBR with Iron Turnings for $80 \%$ Soil $+20 \%$ FS

It is clearly seen from the curves in Fig-12 that initially California Bearing Ratio (CBR) Value increases on addition of iron turnings in on $80 \%$ soil $+20 \%$ foundry sand combination up to a specified value and then on further addition of iron turnings it goes on decreasing. The maximum California Bearing Ratio (CBR) Value was observed on addition of $3 \%$ iron turnings in $80 \%$ soil $+20 \%$ foundry sand combination for both un-soaked and soaked condition samples.

\section{Conclusions}

Based on study and experimental investigation following conclusions were drawn-

- It was observed that with the addition of foundry sand in sandy clayey soil the Maximum Dry Density (MDD) and California Bearing Ratio (CBR) Values of the soil foundry sand mixture initially increased up to a certain value but on further addition of foundry sand in sandy clayey soil the values of Maximum Dry Density (MDD) and California Bearing Ratio (CBR) showed a decreasing trend. Hence it can be concluded that there exists a optimum percentage of foundry sand which was responsible for increased strength of soil.

- It was further observed that with the addition of Iron turnings in soil-foundry sand mixture the Maximum Dry Density (MDD) and California Bearing Ratio (CBR) Values of the soil foundry sand mixture initially increased up to a certain value but on further addition of Iron turnings in soil-foundry sand mixture the values of Maximum Dry Density (MDD) and California Bearing Ratio (CBR) showed a decreasing trend. Hence it can be concluded that there exists a optimum percentage of Iron turnings which was responsible for increased strength of soil-foundry sand mixture.

- It was also observed that addition of 3\%Iron turnings in soil-foundry sand mixture increased the California Bearing Ratio (CBR)Value from $7.20 \%$ to $20 \%$ for un-soaked condition and from $5.2 \%$ to $12 \%$ for soaked condition samples. Hence it can be concluded that Iron Turnings can be used to improve the strength of soil.

\section{Volume 4 Issue 12, December 2015}




\section{International Journal of Science and Research (IJSR) \\ ISSN (Online): 2319-7064}

Index Copernicus Value (2013): 6.14 | Impact Factor (2014): 5.611

- On the basis of study it can also be concluded that foundry sand and iron turnings which are the waste materials can be used for stabilization of weak soil sub-grade material to improve the strength of soil and hence a increase in CBR value will result in reduced crust thickness of road resulting in saving of construction cost.

- Finally it can be concluded that a mixture of $80 \%$ soil, $20 \%$ foundry sand and 3\% iron turnings was found to be the best and appropriate combination resulting in maximum CBR and MDD value. Hence this mix can be considered appropriate for construction of sub-grades specially for rural roads where the traffic volume is on lesser side.

\section{References}

[1] Abichou, T., Benson, C.H., Edil, T.B., \& Freber, B.W. (1998). Using Waste Foundry Sand for Hydraulic Barriers. In: Vipulanandan, C., Elton, D. (Eds.), Recycled Materials in Geotechnical Applications, Geotechnical Special Publication 79. ASCE, Boston, MA, pp. 86-99.

[2] Bhat, S.T. \& Lovell, C.W.(1996). Use of Coal Combustion Residues and Waste Foundry Sands in Flowable Fill, Purdue University-Joint Highway Research Project Report, Federal Highway Administration, Washington, DC, $240 \mathrm{p}$.

[3] Bureau of Indian Standards (1973).Methods of Tests for Soil, Part II, Determination of Water Content of Soil, IS:2720,B.I.S,New Delhi.

[4] Bureau of Indian Standards (1975), Methods of Tests for Soil, Part IV, Grain Size Analysis, IS 2720, B.I.S, New Delhi.

[5] Bureau of Indian Standards (1975).Methods of Tests for Soil, Part V, Determination of Liquid Limit and Plastic Limit. IS:2720, B.I.S, N. Delhi.

[6] Bureau of Indian Standards (1980). Methods of Tests for Soil, Part 3/Sec1: Determination of Specific Gravity, IS:2720,B.I.S, New Delhi.

[7] Bureau of Indian Standards (1980). Methods of Tests for Soil, Part VII, Determination of Water Content- Dry Density Relation using Light Compaction of Soil, IS:2720, B.I.S, New Delhi.

[8] FIRST (Foundry Sand Facts for Civil Engineers), (2004). Federal Highway Administration Report FHWA-IF-04- 004, May, 2004.

[9] Goodhue, M., Edil, T.B., \& Benson, C.H. (2001). Interaction of Foundry Sand with Geo-Synthetics. Journal of Geotechnical and Geo-Environmental Engineering, 127 (4), pp. 353-362.

[10] Javed, S.\& Lovell, C.W.(1995). Uses of Waste Foundry Sand in Civil Engineering. Transportation Research Board Record,1486, pp. 109-113.

[11]Kirk, P.B. (1998). Field Demonstration of Highway Embankment Constructed using Waste Foundry Sand. Ph.D. Dissertation, Purdue University, West Lafayette, IN, 202 p.

[12] Kleven, J.R., Edil, T.B. \& Benson, C. H.(2000). Evaluation of Excess Foundry System Sands for Use as Sub-base Material. Proceedings of the 79th Annual Meeting, Transportation Research Board, Washington, DC.
[13]Mast, D.G. \& Fox, P.J.(1998). Geotechnical Performance of Highway Embankment Constructed using Waste Foundry Sand. In: Vipulanandan, C. \& Elton, D. (Eds.), Recycled Materials in Geotechnical Applications, Geotechnical Special Publication 79. ASCE, Boston, MA, pp. 66-85.

[14] Singh, G. \& Siddique, R. (2012). Effect of Waste Foundry Sand (WFS) as Partial Replacement of Sand on the Strength, UPV and Permeability of Concrete. Construction and Building Materials, Vol. 26(1), pp. 416-422.

[15]IRC:37-2001. Guidelines for the Design of Flexible Pavements. Indian Roads Congress, New Delhi, India.

\section{Author Profile}

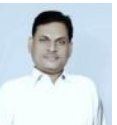

Brajesh Mishra received the B.E. and M.Tech. degrees in Civil Engineering from Madan Mohan Malviya Engineering College, Gorakhpur, India (NowMMMUT) in 1988 and KNIT, Sultanpur, India in 2014 respectively. At present working with U.P. Cane Development Department, Lucknow, responsible for construction of road projects. 